KELSEY FARMER

\title{
REGULATION OF PREDICTION MARKETS UNDER THE FINANCIAL MARKETS CONDUCT ACT 2013
}

Submitted for the LLB (Honours) Degree

Faculty of Law

Victoria University of Wellington

2014 


\begin{abstract}
The Financial Markets Conduct Act 2013 (FMC Act) represents the most substantial overhaul of New Zealand's securities law in recent history. The regulation of derivatives in particular featured high on the agenda as an area in need of reform and, as a result, the FMC Act is much clearer than the Securities Markets Act 1988 with respect to typical derivative agreements. The focus of this paper, however, is on the atypical: the use of derivatives in prediction markets. With a study of New Zealand-based prediction market iPredict, this paper examines whether iPredict will be regulated under the FMC Act and, if so, how it will be regulated. The conclusion reached is that iPredict can operate under the FMC Act only if the Financial Markets Authority (FMA) declares that its contracts are derivatives and grants substantial exemptions from regulatory compliance. This paper then makes recommendations for a more coherent approach to the regulation of prediction markets under the FMC Act.
\end{abstract}

Key terms: prediction markets - financial innovation - information technology Securities Markets Act 1988 - Financial Markets Conduct Act 2013. 


\section{CONTENTS}

I Introduction

.4

II $\quad$ Financial Derivatives.....................................................

A From Antiquity to Today

B Function

III $\quad$ Prediction Markets: An Innovative Use of Derivatives.........................8

IV Regulation of Prediction Markets in New Zealand..........................14

A iPredict

B Regulation under the Securities Markets Act 1988

C Regulation under the Gambling Act 2003

D Regulation under the Financial Markets Conduct Act 2013

1 Will iPredict be regulated under the FMC Act?

2 If so, how will iPredict be regulated under the FMC Act?

(i) Licensed market services provider: derivatives issuer

(ii) Financial product market

V Recommendations

.26

(i) Designation

(ii) Licensed market services provider: prescribed intermediary

VI Conclusion.

VII Bibliography 


\section{INTRODUCTION}

The Financial Markets Conduct Act 2013 (FMC Act) represents the most substantial overhaul of New Zealand's securities law in recent history. ${ }^{1}$ Since the enactment of the Securities Act in 1978, the development of securities law in New Zealand has been marked by piecemeal attempts to patch legislative gaps in reaction to economic downturns and investor losses. This pattern of ad hoc reform added layers of confusion to an already complex area of law to create a regime that was in many respects inconsistent and ineffective. ${ }^{2}$ The FMC Act, on the other hand, was enacted following a comprehensive four year consultation process with key stakeholders, resolving to promote investor confidence and market efficiency. ${ }^{3}$

Financial derivatives in particular featured high on the agenda as an area in need of reform. Regulators worldwide have been devising legislation to increase and clarify the regulation of derivatives in the wake of their precipitous growth and prominence at the heart of the global financial crisis (GFC). ${ }^{4}$ While New Zealand banks (and their Australian parents) were not heavily invested in the problematic derivatives that exacerbated the GFC, and hence did not suffer the same degree of loss as larger markets, ${ }^{5}$ it is critical to harmonise New Zealand's securities regulation with that of the United States, the United Kingdom and Australia to maintain connections with international pools of capital. ${ }^{6}$ New Zealand's low levels of domestic investment in derivatives was, not ironically, another lead impetus of reform. The industry-led Capital Markets Development Taskforce (CDMT) lamented the

\footnotetext{
${ }^{1}$ The Act will replace the Securities Act 1978, Securities Markets Act 1988, Securities Transfer Act 1991, Superannuation Schemes Act 1989, Unit Trusts Act 1960 and parts of the KiwSaver Act 2006.

${ }^{2}$ Shelley Griffiths “Regulating Private Offers of Securities: Time for a Major Rethink” (2009) 15 NZBLQ 105 at 121.

${ }^{3}$ Financial Markets Conduct Act 2013, s 3. Period of consultation taken from release of Review of Securities Law Discussion Paper (Ministry of Economic Development, June 2010).

${ }^{4}$ Dan Awrey “The Dynamics of OTC Derivatives Regulation: Bridging the Public-Private Divide” (2010) 11 European Business Organisation Law Review 155 at 156.

${ }^{5}$ Victoria Stace Securities Law in New Zealand (LexisNexis, Wellington, 2010) at 35.

${ }^{6}$ Hon Lianne Dalziel “Guest Editorial: Securities Markets Regulation: The Minister’s right of reply” (2003) 4 CSLB 29 at 29. Also: Rob Cameron Capital Markets Matter (Capital Markets Development Taskforce, December 2009) at 86.
} 
limited availability of derivatives in New Zealand to be a 'missing market', and identified reform as vital to promote new entries and investment in derivatives markets. ${ }^{7}$

Two key objectives of the FMC Act reform to achieve these ends were to define 'derivative' with greater clarity and establish licensing regimes for derivatives issuers and markets. ${ }^{8}$ While the FMC Act's treatment of derivatives is much clearer with respect to typical derivative agreements, the focus of this paper is on the atypical: the use of derivatives in prediction markets. It is unclear whether prediction markets will be regulated under the FMC Act and, if so, how prediction markets will be regulated. This is not surprising given that reform was certainly not achieved with prediction markets in mind but, as this paper explains, the promise of these innovative markets to generate accurate forecasts on issues of public concern suggests prediction markets should not be left in legal limbo.

This paper proceeds as follows. Part II presents a brief outline of the development and primary functions of derivatives to illustrate the conventional utility of derivatives for healthy capital markets. Part III introduces prediction markets as an innovative use of derivatives. Part IV turns its focus to the New Zealand regulatory environment with a discussion of the fledgling prediction market iPredict; how iPredict has been regulated under the Securities Markets Act 1988; and how iPredict will be regulated, if at all, under the FMC Act. This discussion illustrates that iPredict can operate under the FMC Act only if the Financial Markets Authority (FMA) declares that its contracts are derivatives and grants substantial exemptions from regulatory compliance.

Part V makes recommendations for a more coherent approach to the regulation of prediction markets. The FMA should declare that prediction market contracts are derivatives. Regulations should be passed to include prediction markets as a 'prescribed intermediary service' to allow prediction markets to operate as a licensed market services provider. This paper also makes recommendations for licensing criteria and conditions to ensure the efficient operation of prediction markets.

\footnotetext{
${ }^{7}$ Cameron, above n 6, at 60 .

${ }^{8}$ Review of Securities Law Discussion Paper, above n 3, at $24-25$.
} 


\section{FINANCIAL DERIVATIVES}

\section{A From ANTIQUITY to TODAY}

In essence, derivatives are bilateral agreements the value or expected performance of which is determined by reference to a secondary asset (commonly referred to as the 'underlying'). ${ }^{9}$ This basic formulation of a derivative is not a modern phenomenon; derivatives have been woven into the fabric of commerce for millennia - from ancient China and Mesopotamia, to Medieval Europe, to $17^{\text {th }}$ century Japan and $19^{\text {th }}$ century England and America. Early derivatives were typically used to offset the risk inherent in physical commodities markets such as grain, livestock, textiles and precious metals. ${ }^{10}$ The wheat farmer, for example, would enter into an agreement with a merchant before his crop had grown to sell 500 bushels of wheat for an agreed price to be paid at a future date. The value of this agreement for both the farmer and the merchant would fluctuate depending on the value of wheat in the wider market. If the market value of wheat was above the agreed price at the agreed future date, the merchant receives the most benefit from the derivative. If the value of wheat was below that price, the farmer does. In either case, the risk of doing business was reduced for both parties because their future income or expenditure was determined at the time the agreement was made, and so was not exposed to market movements (due to the weather or availability of wheat, for example). ${ }^{11}$

Sparked by breakthroughs in financial theory, and fuelled by the forces of globalisation, the demise of the Bretton Woods exchange rate system, bank deregulation, and advances in computing software, modern derivatives markets emerged in the 1970 s. ${ }^{12}$ The establishment of a formal derivatives market in New Zealand took a bit longer, and the (now defunct) New Zealand Futures and Options Exchange began trading in $1985 .{ }^{13}$ While engineered from the same basic structures, modern derivatives differ from their historic counterparts in three important respects. First, the vast majority of modern derivatives have an intangible asset as their underlying - typically financial assets such as equity, debt, interest rates, or currencies.

\footnotetext{
${ }^{9}$ John C. Hull Fundamentals of Futures and Options Markets (8 $8^{\text {th }}$ ed, Pearson Education., USA, 2014) at 1.

${ }^{10}$ Awrey, above $\mathrm{n}$ 4, at 158.

${ }^{11}$ Hull, above $\mathrm{n} 9$, at $2-3$.

${ }^{12}$ Awrey, above n 4, at 159.

${ }^{13}$ Christian Hawkesby A primer on derivatives markets (2009) 62 Reserve Bank of New Zealand Bulletin 24 at 24 .
} 
Second, where early derivatives market participants were limited by their physical location and the requirement to deliver the commodity, trades in modern derivatives transcend physical and jurisdictional boundaries. Third, modern derivatives can and often do exhibit dazzling complexity in the variety of ways that the same basic structures are networked with other derivatives and market participants. ${ }^{14}$

\section{B FUNCTION}

Derivatives perform an important function as a tool to redistribute risk. With derivative contracts, market participants can isolate certain risks inherent in the underlying they are dealing with, and transfer those risks to others who are more willing to bear them. ${ }^{15}$ The underlying is usually a commodity or intangible financial asset - but the types of derivatives that can exist are limited only by regulation and the imaginations of the contracting parties. ${ }^{16}$ Derivatives effectively allow participants to construct their desired risk profile provided they can find willing counterparties to take on their unwanted risks.

The main reasons for redistributing risk with derivatives are hedging and speculation. Hedgers seek to reduce or eliminate risk (as in the example of the wheat farmer and merchant). ${ }^{17}$ Determination of the future price of a derivative agreement at an earlier date means that hedgers may forgo some profits if the underlying does not perform as expected, but the risk of loss is reduced as the derivative create price certainty for transactions which may not take place for several months. ${ }^{18}$ For example, New Zealand dairy producers often sell derivatives ('futures') on the NZX Dairy Futures exchange to hedge against the risk of price fluctuations in whole milk power. ${ }^{19}$ This enables dairy producers to undertake activities that they would otherwise be unwilling or unable to do if they had to accept market

\footnotetext{
${ }^{14}$ Awrey, above n 4, at 159.

${ }^{15}$ Norman Menachem Feder “Deconstructing Over-The-Counter Derivatives” (2002) Columbia Business Law Review 677 at 682.

16 Timothy E. Lynch "Derivatives: A Twenty-First Century Understanding (2011) 43 Loyola University of Chicago Law Journal 1 at $24-27$.

${ }^{17}$ Awrey, above n 4, at 160.

${ }^{18}$ Feder, above n 15 , at 717.

${ }^{19}$ NZX Guide to Dairy Futures: NZX Derivatives Market (NZX Limited, 2013) at 14.
} 
risk. In turn, hedging increases efficiency to support a well-functioning market in milk powder. ${ }^{20}$

Speculators seek to profit from exposure to risk by predicting market movements. Where hedgers want to avoid exposure to adverse movements in the price of an underlying to protect their business, speculators do not usually have a direct interest in the underlying and instead wish to take a position in the market as a 'gamble'. ${ }^{21}$ Speculation has been criticised as adding unnecessary risk to financial systems and, indeed, excessive leverage generated by banks' speculative use of derivatives severely magnified the losses that caused the GFC. ${ }^{22}$ That said, speculation is neither inherently positive nor negative. It is only when speculation is widely used for suboptimal risk-taking that market stability is jeopardised. ${ }^{23}$ More commonly, speculators play an important role in providing liquidity to the market and acting as counterparties for hedgers. ${ }^{24}$ Speculation can also perform a public good as a means by which to aggregate information through price discovery, such as the use of derivatives in prediction markets. ${ }^{25}$

\section{PREDICTION MARKETS: AN INNOVATIVE USE OF DERIVATIVES}

The preceding discussion demonstrates that the value of all derivatives is inextricably tied to an underlying, together with another dynamic ingredient: time. Specifically, time- $X$ in the future. Public interest in the future value of an asset or event is pervasive and not limited to financial markets. In fact, each individual, company and government makes predictions about the future every day to inform their decision-making. The accuracy of the information used to make these predictions is therefore of upmost importance. ${ }^{26}$ In pursuit of accuracy, decision-makers regularly consult their experience, defer to experts and poll their peers. Recent experiments in financial innovation, however, suggest that prediction markets can

\footnotetext{
${ }^{20}$ Cameron, above n 6, at 60 .

${ }^{21}$ Feder, above n 15, at 719.

${ }^{22}$ Katia D’Hulster The Leverage Ratio: A New Binding Limit on Banks (The World Bank Group, December 2009) at 1

${ }^{23}$ Awrey, above n 4, 178.

${ }^{24}$ Dan Awrey “Complexity, Innovation, and the Regulation of Modern Financial Markets” (2012) 2 Harvard Business Law Review 235 at 266.

25 Justin Wolfers and Eric Zitzewitz "Prediction Markets” (2004) 18 The Journal of Economic Perspectives 107 at 108.

${ }^{26}$ George Bragues "Prediction Markets: The Practical and Normative Possibilities for the Social Production of Knowledge” (2009) 6 Episteme 91 at 92.
} 
provide a far more efficient and accurate metric of probability - the price signal. ${ }^{27}$ This Part illustrates how prediction markets harness financial incentives to produce socially useful predictions which often outperform conventional forecasting tools. ${ }^{28}$

Prediction markets are speculative exchanges where individuals trade derivative contracts the values of which depend on uncertain future events. In other words, a contract promises to pay a specified amount if an underlying event occurs, and nothing if it doesn't. ${ }^{29}$ The underlying event may theoretically be any occurrence which is clear and easily adjudicated; ${ }^{30}$ for example, the event that David Cunliffe departs as leader of the Labour Party in 2014, or New Zealand is elected to the UN Security Council for 2015/16. ${ }^{31}$ Traders seek to profit from their speculations about the probability of an underlying event by buying or selling the relevant contracts with other traders. Where a trader believes that the contract is undervalued (i.e. the event is more likely to occur than the price reflects), he or she will buy the contract from other traders with the expectation of receiving a payout when the contract expires. Where a trader believes the contract is overvalued (i.e. the event is less likely to occur than the price reflects), he or she will sell the contract to other traders to profit from what he or she perceives to be their poor judgment. ${ }^{32}$ These trades are effected by a continuous double auction mechanism, where buyers submit bids, sellers submit asking prices, and the mechanism executes the trades whenever the two sides of the market reach a mutually agreeable price. ${ }^{33}$

The valuable information that a prediction market produces is the price of the traded contract. ${ }^{34}$ The contract price is directly proportional to the market's belief about whether the event will occur as traders are either more or less willing to take on the risk that the event

\footnotetext{
${ }^{27}$ Ryan P. McCarthy “Information Markets as Games of Chance” (2007) 155 University of Pennsylvania Law Review 749 at 749.

${ }^{28}$ Conventional forecasting tools identified as polls; structural models; time series models; and less formal methods such as focus groups, subcommittees; interviews of knowledgeable parties and expert panels.

${ }^{29}$ Wolfers and Zitzewitz, above n 25, at 109.

${ }^{30}$ Wolfers and Zitzewitz, above n 25, at 120.

31 These contracts were trading at the time of writing on iPredict <www.ipredict.co.nz>

${ }^{32}$ Shaun McGirr and Rob Salmond "2008: Opinion Polls and Prediction Markets in New Zealand” in Stephen Levine and Nigel S. Roberts (eds.) Key to Power: The General Election of 2009 (Victoria University Press, Wellington, 2010) 255 at 259.

${ }^{33}$ Wolfers and Zitzewitz, above n 25, at 120.

${ }^{34}$ Rebecca Haw Allensworth "Prediction Markets and the Law: A Skeptical Account” (2009) 122 Harvard Law Review 1217 at 1218.
} 
will not occur. The price signal thereby provides a continuously updated probability estimate of the event actually taking place. ${ }^{35}$ For example, if contracts for "New Zealand Government to achieve Budget operating balance ABOVE 0.5\% of GDP in 2014/15 (surplus)” are trading at $\$ 0.22$ today, and that contract promises to pay the holder $\$ 1.00$ if the event occurs, then the price reflects the current belief of the market that government is 22 percent likely to achieve a budget operating balance above 0.5 percent of GDP in 2014/15. ${ }^{36}$ The price can therefore be read as a prediction formulated from the aggregation of a vast range of information that diversely situated traders have to contribute. ${ }^{37}$ This information can then be compared to and even supplement official forecasts, such as that issued by the Minister of Finance on the same question. ${ }^{38}$

Support for the proposition that the information produced by prediction markets is likely to outperform conventional forecasting tools is drawn from the efficient markets hypothesis (EMH) and "many minds" arguments, and vindicated by empirical evidence. The EMH asserts that the prices of financial products always incorporate all relevant information. ${ }^{39}$ This is because investors have a profit incentive to exploit any information not contained in prices and hence will do so as quickly as possible before other investors take advantage of the unassimilated information. According to the EMH, therefore, the current price represents the best estimate about the future prospects of a financial asset. ${ }^{40}$

The same market forces are at play in prediction markets. Financial incentives are thought to produce a price-signalled prediction which is more reliable than an individual's stated prediction because, as a self-interested market participant, his or her interest in making a profit weighs against any bias that he or she has. ${ }^{41} \mathrm{~A}$ political expert, for example, may be

\footnotetext{
${ }^{35}$ McCarthy, above n 27, at 751.

${ }^{36}$ This contract was trading at the time of writing on iPredict <ipredict.co.nz>: "This contract pays $\$ 1$ if the New Zealand Government's Half Year Economic and Fiscal Update 2015, expected to be published in December 2015, reports that the total Crown operating balance before gains and losses in the 2014/15 financial year was ABOVE $0.5 \%$ of GDP (i.e. a surplus of MORE THAN 0.5\% of GDP); otherwise it pays \$0.00.”

${ }^{37}$ Cass R. Sunstein “Group Judgments: Statistical Means, Deliberation, and Information Markets” (2005) 80 New York University Law Review 962 at 1034.

${ }^{38}$ Bill English Budget Policy Statement (New Zealand Treasury, December 2013) at 5.

${ }^{39}$ Milton Friedman and Rose Friedman Free to Choose (Penguin Books, Australia, 1981) at 33 - 36.

${ }^{40}$ Eugene F. Fama "Efficient Capital Markets: A Review of Theory and Empirical Work" 25 The Journal of Finance 383 at $383-384$.

${ }^{41}$ Allensworth, above n 34, at 1220.
} 
biased to present certain facts in a way that supports his or her academic publications or because he or she is required to toe the party line. However, by purchasing a contract, he or she is required to "put his or her money where his or her mouth is". The anonymity of the market reinforces traders' objectivity because their reputation remains intact even if he or she decides to change their position on an issue from that stated publicly. ${ }^{42}$

The EMH also explains how prediction markets can overcome problems of inaccuracy in deliberative bodies. Deliberative bodies, such as focus groups and subcommittees, are often more effective than individuals at aggregating information, weighing alternatives, and making decisions. ${ }^{43}$ They are, however, particularly vulnerable to cognitive errors resulting from groupthink dynamics, group polarisation, and overemphasis on shared information at the expense of unshared information. ${ }^{44}$ Deliberative groups also have the insidious consequence of privileging group members with the best rhetorical skills, the possession of which is not necessarily correlated with sound judgment. ${ }^{45}$ Especially where information is confidential or critical of the organisation who employs the group, members have little incentive to contribute as doing so may come at a high personal cost. Conversely, prediction markets create financial incentives for individuals to critically evaluate group discussion with a view to independently disclosing all the information they hold (through trading) without negative repercussions. ${ }^{46}$ In addition to providing incentives for truthful revelation, the possibility of profit encourages individuals to become better informed; ${ }^{47}$ to search for, interpret and trade on the information accessible to them. ${ }^{48}$ This research will be reflected in the market price. ${ }^{49}$

\footnotetext{
42 Sunstein, above 37, at 1026.

43 Allensworth, above n 34, at 1217.

${ }^{44}$ Sunstein, above $\mathrm{n} 37$, at 1048.

45 Bragues, above n 26, at 102.

${ }^{46}$ Sunstein, above $\mathrm{n} 37$, at 1024.

${ }^{47}$ James Surowieki The Wisdom of Crowds: Why the Many Are Smarter Than the Few and How Collective Wisdom Shapes Business, Economies, Societies, and Nations (Doubleday, New York, 2004), at 23 - 39.

${ }^{48}$ Tom W. Bell “Government Prediction Markets: Why, Who, and How” 166 Penn State Law Review 403 at 418.

${ }^{49}$ The EMH does not require that all traders are well-informed. It is the marginal, not the average, trade that sets the prices: Sunstein, above n 37 at 1035: "In the Iowa Electronic Markets, for example, it turns out that $85 \%$ of the traders do not seem to be particularly wise. They hold onto their shares for a long period and then simply accept someone else's prices. The predictions of the market are driven by the other $15 \%$ - frequent traders who post their offers rather than accepting those made by other people”.
} 
"Many minds” arguments also support the accuracy of prediction markets. Such arguments explore the possibility that large groups of people, by virtue of their size and independence, give better answers to difficult questions than traditional means. 50 "Many minds" arguments draw from the theory of Friedrich Hayek, who criticised socialism for its assumption that the knowledge required to optimise public resources is of a quality that can be grasped by any single individual or agency. Unlike the general laws and methods of the natural sciences, Hayek argued that the knowledge required to determine the appropriate means to satisfy the ends of society's members is too complex - especially where the relevant information is widely dispersed and subject to constant change. The problem for society, then, is how to optimally allocate resources in a way that recognises peoples' bounded rationality. ${ }^{51}$ This dilemma is solved, according to Hayek, with the price system; a signal responsive to the actions of all members over time by which everyone is presented with a single number to make calculations about the means to fulfil their ends. ${ }^{52}$

The Hayekian view can be extrapolated to prediction markets even though the primary purpose of the market is forecasting, not resource allocation. Prediction markets are accurate because they provide an algorithm for aggregating diverse beliefs about an event. ${ }^{53}$ The knowledge required to form an accurate forecast, such as the possibility that government will achieve a budget operating balance above 0.5 percent of GDP, is distributed across hundreds, if not thousands, of individuals, each with their own perspective (in our example, across all government departments and agencies). A literal marketplace of ideas, prices constantly update as individuals trade on new information, and the price signal operates as a coordinating device to converge on an otherwise elusive best estimate. ${ }^{54}$

\footnotetext{
${ }^{50}$ Surowieki, above n 47. The phrase "many minds" was coined by Cass R. Sunstein A Constitution of Many Minds: Why the Founding Document Doesn't Mean What It Meant Before (Princeton University Press, New Jersey, 2009).

${ }^{51}$ Friedrich Hayek “The Use of Knowledge in Society” (1945) 35 The American Economic Review 519 530.

52 Bragues, above n 26, at 97.

${ }^{53}$ Emile Servan-Schreiber and others, “Prediction Markets: Does Money Matter?” (2004) Electronic Markets 243 at 244.

${ }^{54}$ Miriam A. Cherry and Robert L. Rogers "Prediction Markets and the First Amendment” (2008) University of Illinois Law Review 833 at 837. The expression “a marketplace of ideas” refers to Oliver Wendell Holmes' analogy of free speech. The authors' here argue that the expressive element inherent in prediction markets means that participation in such a market should be protected by the First Amendment.
} 
Theories supporting the superior accuracy of prediction markets are borne out by empirical evidence. The Iowa Electronic Markets (IEM) were established in 1988 by the University of Iowa business department. ${ }^{55}$ Comparison of IEM predictions to 964 polls over the five US Presidential elections from 1988 to 2000 revealed that IEM achieved a prediction closer to the eventual outcome 75 percent of the time, whether the prediction is made on the eve or several months in advance of the election. ${ }^{56}$ In a corporate context, researchers at HewlettPackard found that employees, when enrolled as prediction traders, generated forecasts of printer sales that outperformed the firm's official projections 15 out of 16 times. ${ }^{57}$ Closer to home, New Zealand prediction market iPredict reports to have been more accurate than 82.4 percent of political polls leading up to the 2011 New Zealand general election. ${ }^{58}$

The most significant practical obstacles to the development of prediction markets are liquidity, legitimacy and legal barriers. These obstacles are interrelated. Liquidity is essential for predictive accuracy. Illiquid markets convey poor predictions because the price signal is unlikely to assimilate a wide range of insights and the last recorded trade is apt to contain stale information. ${ }^{59}$ For the same reasons, illiquid markets are more susceptible to speculative bubbles and information cascades. ${ }^{60}$ Until liquidity (and hence the accuracy) of prediction markets is firmly established, individuals, companies and governments will understandably be hesitant to rely on market predictions in their decision-making. ${ }^{61}$ As shown by IEM and iPredict, illiquidity can be overcome with proper market design and legitimacy may be expected to strengthen over time if the market produces consistently accurate forecasts. Experimentation with market design, however, can only occur if legal regulation permits prediction markets to operate at all. ${ }^{62}$

\footnotetext{
55 Allensworth, above $n$ 34, at 1221.

56 Joyce E. Berg, Forrest D. Nelson, and Thomas A. Reitz "Prediction market accuracy in the long run" (2008) 24 International Journal of Forecasting 283 at 298.

${ }^{57}$ Kay-Yut Chen and Charles R. Plott, Information Aggregation Mechanisms: Concept, Design and Implementation for a Sales Forecasting Problem (California Institute of Technologies, 2002) at 13 - 16. See also for prediction markets in the corporate context: Bo Cowgill, Justin Wolfers and Eric Zitzewitz Using Prediction Markets to Track Information Flows: Evidence from Google (Dartmouth College, 2008).

${ }^{58}$ Statistics available from iPredict upon request. Data relative to polls available: McGirr and Salmond, above $\mathrm{n} 32$, at 269.

${ }^{59}$ Bragues, above n 26, at 100.

${ }^{60}$ Sunstein, above $\mathrm{n} 37$, at 1039.

${ }^{61}$ Sunstein, above $\mathrm{n} 37$, at 1041.

${ }^{62}$ Kenneth J. Arrow and others “The Promise of Prediction Markets” (2008) 320 Science 877 at 878.
} 


\section{REGULATION OF PREDICTION MARKETS IN NEW ZEALAND}

\section{A IPREDICT}

In 2008, iPredict launched as New Zealand's first and only prediction market for political, economic and social events. ${ }^{63}$ A joint venture between Victoria University of Wellington and the New Zealand Institute for the Study of Competition and Regulation, iPredict is intended primarily as a tool for education, research and policy analysis. The market involves low value contracts and is accordingly not intended as a mechanism for investment. ${ }^{64}$ iPredict reports to have 8000 registered traders, of which 600 - 700 actively trade each month. The journey to operation, however, was not straightforward. In their words: ${ }^{65}$

There were two main obstacles [to be operational in time for the 2005

New Zealand election]: one, we didn’t have any software, and two, we didn't have regulatory approval to run a real money market. As it turns out, by far the easiest of those two problems was to develop software required to run these markets.

Prediction markets present unique and difficult legal issues because they resemble, but are not equivalent to, two other highly regulated products: derivatives and gambling. The close connection between gambling and derivatives used for speculation is often noted. ${ }^{66}$ The distinction may be built on policy rather than definition: "[t]he history of financial regulation... can be roughly summarised as everything being banned as gambling (or usury) until an exception was granted for some newly legitimised higher purpose” ${ }^{67}$ Legitimacy of prediction markets is currently fragile, largely because the idiosyncratic purpose of the

${ }^{63}$ Futures Contracts (iPredict Limited) Declaration and Exemption Notice 2008.

${ }^{64}$ iPredict "Terms of Service" <ipredict.co.nz> and Futures Contracts (iPredict Limited) Declaration and Exemption Notice 2008.

65 iPredict "About iPredict” <ipredict.co.nz>

66 Thomas Lee Hazen "Disparate Regulatory Schemes for Parallel Activities: Securities Regulation, Derivatives Regulation, Gambling, and Insurance” (2005) 24 Annual Review of Banking and Finance Law 375 at 377 ("One thing that investing, hedging, insurance, and gambling have in common is that they all involve risk-taking, while only the first three activities are generally seen as involving risk-shifting and other legitimate economic benefits”); Christine Hurt "Regulating Public Morals and Private Markets: Online Securities Trading, Internet Gambling, and the Speculation Paradox” (2006) 86 Boston University Law Review 371 at 373 - 374; Lynn A. Stout "Why the Law Hates Speculators: Regulation and Private Ordering in the Market for OTC Derivatives” (1999) 48 Duke Law Journal 701 at 715.

67 Robin Hanson “Shall We Vote on Values, But Bet on Beliefs?” Working Paper, George Mason University, 2000. See also: Robin Hanson "Shall We Vote on Values, But Bet on Beliefs?” (2013) 21 The Journal of Political Philosophy 151. Also: Nelson Rose “How Securities Trading Became Legally Not Gambling” (2011) 15 Gaming Law Review and Economics 249. 
markets - information aggregation to formulate predictions - fits poorly within existing models of regulation. ${ }^{68}$ As this paper explains, how iPredict is regulated depends on whether the purpose of the market is considered a legitimate end to be pursued within securities law or mere regulatory arbitrage to circumvent gambling legislation. ${ }^{69}$ In New Zealand, regulators have permitted the operation of iPredict to date under the Securities Markets Act 1988 (“SM Act”). The future of iPredict under the FMC Act is uncertain. This Part illustrates how iPredict sits in a legal grey area between securities and gambling legislation, and seeks to find a place for this innovative market.

\section{B SECURITIES MARKETS ACT 1988}

iPredict is currently regulated as an authorised futures dealer under the SM Act. This is possible because the Securities Commission and the FMA declared that the contracts traded on iPredict are futures contracts because "they are valued according to a future outcome, with that value being determined at the time of their commencement, and they are settled by payment of money rather than by delivery of any goods”. ${ }^{70}$ This reasoning, while true, offers little by way of a principled distinction between derivatives and gambling. In fact, the same expression could be used to describe a horse racing bet or lottery ticket. If the distinction between derivatives and gambling is built on policy rather than definition, the declaration suggests that the FMA is prepared to endorse the potential of iPredict to generate socially useful predictions - at least in the context of university research. The declaration permits iPredict to operate until 20 November 2016, at which time iPredict will become subject to either the FMC Act or the Gambling Act 2003. ${ }^{71}$

\section{REGULATION UNDER THE GAMBLING ACT 2003}

The Gambling Act 2003 (“Gambling Act”) prohibits all forms of online gambling that are not promoted by the Lotteries Commission; authorised under the Racing Act 2003; conducted by an operator outside New Zealand; or take the form of a sales promotion

\footnotetext{
${ }^{68}$ Cherry and Rogers, above $n$ 54, at 834.

${ }^{69}$ Robert W. Hahn and Paul C. Tetlock “A new approach for regulating information markets” (2006) 29 Journal of Regulatory Economics 265 at 269.

${ }^{70}$ Futures Contracts (iPredict Limited) Declaration and Exemption Notice 2008, reg 7.

${ }^{71}$ Futures Contracts (iPredict Limited) Declaration and Exemption Amendment Notice (No 2) 2013, reg 4.
} 
lottery. ${ }^{72}$ As trading on iPredict occurs entirely through its online platform and none of these exclusions apply, regulation under the Gambling Act would render the market illegal.

The Gambling Act defines 'gambling' as staking consideration on the outcome of something seeking to win money when the outcome depends wholly or partly on chance. ${ }^{73}$ This definition is intentionally wide to include games of mixed chance and skill. ${ }^{74}$ In TVWorks $v$ Department of Internal Affairs, the Court of Appeal held that poker tournaments are gambling because chance is inherent in a player betting on the value of his or her hand where he or she has no control over the hand dealt to other players. ${ }^{75}$ Poker can be distinguished from conventional sporting events such as yachting or golf, according to the Court, because skill is the predominant and normally decisive feature of conventional sports. ${ }^{76}$

In prediction markets, trading often involves skill in that traders must assess information to estimate the likelihood of an event. Traders also have a greater degree of control over the information they hold in that they can conduct research for better information in a way that poker players cannot. ${ }^{77}$ Research, however, is limited by how accessible the relevant information is. Whether it is skill or chance that predominates will therefore depend on the subject of the underlying. Since prediction markets are predicated on the idea that a single trader does not usually hold all relevant information, it is likely that many contracts will depend at least partly on chance thereby bringing the contracts traded on iPredict within the definition of gambling. It is therefore essential for iPredict to situate itself in securities law if it is to continue operating. ${ }^{78}$

\footnotetext{
${ }^{72}$ Gambling Act 2003, s 9(2)(b).

${ }^{73}$ Gambling Act 2003, s 4.

74 TVWorks $v$ Department of Internal Affairs [2012] NZCA 160 at [20].

75 TVWorks v Department of Internal Affairs, above n 74, at [23].

${ }^{76}$ TVWorks v Department of Internal Affairs, above n 74, at [25].

77 McCarthy, above $n$ 27, at 770.

78 An alternative strategy for iPredict is to use "play money" rather than real money. Prediction market Hollywood Stock Exchange has had success with this tactic. However, iPredict reports that its experiments with play money markets are not nearly as accurate as its real money market. See also: Servan-Schreiber and others, above n 53 .
} 


\section{REGULATION UNDER THE FINANCIAL MARKETS CONDUCT ACT 2013}

The FMC Act provides an entirely different regulatory framework than the Gambling Act. Rather than prohibiting certain products, the FMC Act seeks to promote market efficiency through mandatory disclosure of information by issuers of financial products. Disclosure is thought to promote market efficiency by reducing information asymmetries between investors and those who offer financial products to enable investors to make wiser financial decisions. ${ }^{79}$ In particular, regulated disclosure is aimed at preventing fraud, misrepresentation and mispricing of risk. ${ }^{80}$ The need to correct information asymmetries, however, will not always outweigh the expense associated with disclosure. Accordingly, offers of financial products require disclosure unless an exclusion in Schedule 1 applies. ${ }^{81}$

The FMC Act also promotes market efficiency, in particular by encouraging confident participation in the markets, through regulation of specific financial sector participants and financial product markets. The FMC Act creates a licensing regime for specific financial sector participants which is designed to be risk-based and flexible to ensure competency and suitable disclosure. ${ }^{82}$ Three of these licenses are discussed below. The FMC Act largely replicates the SM Act with respect to regulation of financial product markets but incorporates new exemptions to tailor the requirements of the FMC Act to smaller "stepping stone" markets. ${ }^{83}$ While the FMC Act allows for a great deal of regulatory flexibility, it is unclear whether iPredict will be regulated under the FMC Act and, if so, how iPredict will be regulated.

\footnotetext{
${ }^{79}$ Stace, above n 5, at 15.

${ }^{80}$ Jenny Chen and Susan Watson "Investor Psychology Matters: Is a Prescribed Product Disclosure Statement a Supplement for Healthy Investment Decisions?” (2011) 17 NZBLQ 412 at 414.

${ }^{81}$ Chris Holland "Financial Markets Conduct Act - An Overview, Part One” (2013) CSLB 77 at 80.

${ }^{82}$ Office of the Minister of Commerce Financial Markets Conduct Regulations Paper 4 - Licensing Regimes (Cabinet Business Committee, September 2013) at 3.

83 A Guide to the Financial Markets Conduct Act 2013 Reforms (Financial Markets Authority, November 2013) at 19.
} 


\section{Will iPredict be regulated under the FMC Act?}

The FMC Act applies to "financial products” which are defined as equity, debt, managed investment products, and derivatives. ${ }^{84}$ The legal status of the contracts traded on iPredict is not clarified by the FMC Act, under which a derivative: ${ }^{85}$

(4) Means an agreement in relation to which the following conditions are satisfied:

(i) under the agreement, a party to the agreement must, or may be required to, provide at some future time consideration of a particular kind or kinds to another person; and

(ii) that future time is not less than the time, prescribed for the purposes of this subparagraph, after the time at which the agreement is entered into; and

(iii) the amount of the consideration, or the value of the agreement, is ultimately determined, is derived from, or varies by reference to (wholly or in part) the value or amount of something else (of any nature whatsoever and whether or not deliverable).

The relevant agreements are those between traders on iPredict's online platform. iPredict is the market provider and is not party to the trades. ${ }^{86}$ In purchasing a contract on iPredict, Trader A incurs an obligation to pay the contract purchase price to Trader B and acquires a contingent right to receive the payout sum $(\$ 1.00)$ from the clearing house held funds of Trader B if the underlying event occurs in the future. As counterparty, Trader B acquires a right to receive the contract purchase price from the clearing house held funds of Trader $\mathrm{A}$ and incurs a contingent obligation to pay the payout sum to Trader $\mathrm{A}$ if the underlying event occurs in the future. The value of the contract therefore depends on whether or not the underlying event occurs. ${ }^{87}$

\footnotetext{
${ }^{84}$ Financial Markets Conduct Act 2013, s 7.

${ }^{85}$ Financial Markets Conduct Act 2013, s 8(4).

86 iPredict "Terms of Service” <ipredict.co.nz $>$.

87 iPredict "Terms of Service" <iPredict.co.nz>: Traders must open an account and deposit funds with iPredict's clearing house trust account - Predictions Clearing Limited - before trading. In addition to trading, contracts are made available for purchase by traders in two ways: short-selling and bundling. Short-selling is where a trader sells a futures contract at today's price that is not owned by the trader, and the trader will be required to pay for the contract in the future. A trader will short-sell where he or she expects the purchase price to fall. Bundling occurs when a market consists of several contracts each of which have the same payout amount and are mutually exclusive. A trader will purchase bundles to take advantage of arbitrage opportunities. Importantly, both short-selling and bundling ensure that bets are fully funded and the market does not make a loss.
} 
The pertinent issue for iPredict is that the definition of derivative appears to exclude agreements where the contract value is derived from an underlying which has no quantifiable "value" or "amount” independent of the contract, such as contracts for National to win the election. This is significant because contracts which do not rely on a value or amount (such as an index or commodity) are by far the most popular of the contracts traded on iPredict. Their legal status is therefore crucial to the market's liquidity and consequent accuracy. ${ }^{88}$

Financial products that are not included in the financial product definitions but which fall within a broad definition of "security" may nevertheless be designated by the FMA to be a financial product. ${ }^{89}$ A security for this purpose is any arrangement that is intended to have the effect of a person making an investment or managing a financial risk. ${ }^{90}$ The FMA then must only exercise its designation power if the designation is necessary or desirable to promote the purposes of the FMC Act, ${ }^{91}$ namely confident and informed participation of businesses, investors and consumers in financial markets; the development of fair, efficient and transparent financial markets;92 to provide for timely, accurate and understandable information for persons making decisions relating to financial products and services; to ensure appropriate governance arrangements; to avoid unnecessary compliance costs; and to promote innovation and flexibility in financial markets. ${ }^{93}$

Contracts on iPredict are not securities in the sense of investment but they do involve managing financial risk. The requirement that a security is used to manage risk is drawn from the Australian Corporations Act 2001 which provides that a person manages financial risk if they manage the consequences to them of particular circumstances happening, or avoid or limit the financial consequences of fluctuations in receipts or costs. ${ }^{94}$ Contracts are traded on iPredict to manage the profit or loss that will result if the underlying event occurs as the likelihood of that event happening fluctuates. This involves management of traders'

\footnotetext{
88 iPredict "Most Traded" <iPredict.co.nz>.

${ }^{89}$ Financial Markets Conduct Act, s 562.

${ }^{90}$ Financial Markets Conduct Act, s 6.

${ }^{91}$ Financial Markets Conduct Act, s 563.

92 Financial Markets Conduct Act, s 3.

${ }^{93}$ Financial Markets Conduct Act, s 4.

${ }^{94}$ Australian Corporations Act 2001 (Cht), s 763C.
} 
risk profiles unlike gambling arrangements wherein participants cannot bet out of a risky position. ${ }^{95}$

Risk management on iPredict consequently involves management of risks generated solely by speculation, as the risk would not exist but for the prediction market contract (unlike hedging in commodities markets). This provokes an issue about whether traders' ability to manage the level of risk they are exposed to is sufficient to distinguish the contracts as securities instead of gambling arrangements. Unlike the SM Act, the FMC Act does not contain a safe harbour for derivatives against prosecution under the Gambling Act. ${ }^{96}$ Instead, the explanatory note to the FMC Act takes the view that "legitimate financial markets transactions, whether used for hedging or investment purposes, are not gambling within the meaning of the Gambling Act”. ${ }^{97}$ This phrase was adapted from Hobhouse $\mathrm{J}$ in Morgan Grenfell, in considering whether an interest rate swap agreement was subject to UK gambling legislation: ${ }^{98}$

In the context of interest rate swap contracts entered into by parties or institutions involved in the capital market and the making or receiving of loans, the normal inference will be that the contracts are not gaming or wagering but are commercial or financial transactions to which the law will, in absence of some other consideration, give full recognition and effect.

That this view is included in the explanatory note rather than the FMC Act itself reflects the opinions of submitters on the FMC Bill that the concept of legitimate financial market transactions will largely be a discretionary matter based on facts and circumstances. ${ }^{99}$

\footnotetext{
${ }^{95}$ McCarthy, above n 27, at $770-771$.

${ }^{96}$ Securities Markets Act 1988, s 40.

${ }^{97}$ Financial Markets Conduct Bill (342-1) (explanatory note) at 2. The use of "hedging or investment purposes" does not necessarily exclude derivatives used sole for speculation. The Review of Securities Law Discussion Paper, above n 8, made similar comments, at 33: "The definition of derivatives will require that a material feature of the offer is the possibility of earning a positive financial return from the investment, or hedging financial risk (i.e. this covers derivatives used for both speculation and hedging”.

${ }^{98}$ Morgan Grenfell \& Co Ltd v Welwyn Hatfield District Council (Islington London Borough Council, third party) [1995] 1 All ER 1 at $10 \mathrm{~d}$.

${ }^{99}$ Financial Markets Conduct Bill Exposure Draft: Table of Submissions and Ministry Comments (Ministry of Economic Development, October 2011): Institute of Finance Professionals New Zealand Inc. submission and Bank of New Zealand submission, at 18.
} 
This paper proposes that the contracts traded on iPredict should be considered legitimate financial market transactions by virtue of their utility to generate accurate forecasts on issues of public concern. The positive externality of accurate forecasting admittedly is not the traders' purpose, and is remarkably different than the commercial purposes which will usually distinguish legitimate financial market transactions from gambling. ${ }^{100}$ However, unlike gambling, prediction markets have potential to improve public and private decision-making, and education and research, which are unquestionably legitimate ends. In the author's view, innovations which have these positive externalities should be encouraged and the key question for the FMA should be whether the subject of the contracts is a "game" or an important event in which there is legitimate public interest. The probabilities of many political, economic and social events have significant implications for the public, and would thereby satisfy this legitimate public interest requirement. ${ }^{101}$

The FMA's decision on this question will be informed by the next stage of the FMA's inquiry: whether declaring that the contracts traded on iPredict are derivatives is necessary or desirable to promote the purposes of the FMC Act. ${ }^{102}$ Designation is necessary to promote market innovation in this instance because not to do so would render iPredict illegal under the wide definition of gambling in the Gambling Act. Designation would enable the development of a relatively low-risk market in which consumers can participate and become better informed about how markets operate. Accordingly, this paper recommends that the FMA continues its policy under the SM Act and declares that the contracts traded on iPredict are derivatives under the FMC Act.

\section{If so, how will iPredict be regulated?}

The distinctive features of iPredict which ought to guide its regulation are that the market solicits the public to trade, many of whom are retail traders; the market is relatively small;

\footnotetext{
${ }^{100}$ Hahn and Tetlock, above n 69, at 269: In practice, there is no simple way to know a person's motives for trading in a market. Gambling may occur in a large number of markets, including stock markets. Prediction market traders may be motivated by the forecast. See also for discussion about why prediction markets should be regulated at all.

${ }^{101}$ Hahn and Tetlock, above n 69, at 274 where the authors' propose a similar “economic purpose test”.

102 Financial Markets Conduct Act, s 563.
} 
iPredict holds traders' money; and the traded derivatives are not complex but involve an element of risk. ${ }^{103}$ Given the close connection between derivatives and gambling, it is also important that regulation ensures iPredict is limited to offering derivatives with underlyings in which there is legitimate public interest to justify the distinction.

Under the FMC Act, iPredict could be regulated as a licensed derivatives issuer or a financial product market. This Part illustrates how neither of these categories facilitate the development and efficient operation of iPredict. iPredict can operate under the FMC Act only if the FMA grants substantial exemptions from regulatory compliance.

\section{(i) Licensed Market Services Provider: Derivatives Issuer}

The category of 'authorised futures dealer' is removed from the FMC Act. Instead, transitional provisions prescribe that authorised futures dealers must be treated as holding a financial services licence, ${ }^{104}$ and the majority of futures dealers will be licensed as derivatives issuers. ${ }^{105}$

A derivatives issuer is the person who enters into the derivative, provided that person is in the business of entering into derivatives. ${ }^{106}$ As this paper explained, iPredict is the market provider and is not party to the trades. The traders enter into the derivatives, but they are not "in the business" of entering into derivatives; most trade recreationally. ${ }^{107}$ In effect, there is no derivatives issuer to license. This unusual result is due to the fact that iPredict operates much more like an exchange than a dealer. The SM Act definition of futures dealer permitted the FMA to declare any conduct to be dealing in a futures

\footnotetext{
103 iPredict "Terms of Service" <ipredict.co.nz>

${ }^{104}$ Financial Markets Conduct Act, sch 4, cl 45.

105 Office of the Minister of Commerce, above n 82, at 9.

${ }^{106}$ Financial Markets Conduct Act, s 11 and s 6.

${ }^{107}$ Financial Markets Conduct Bill Exposure Draft, above n 99, at 10. Ministry comment: "The intention is that carrying on the business of an activity does not require that the activity is the person's principal business but that one-off or occasional transactions would not be caught. It may be difficult to define further for the purposes of this Bill”.
} 
contract. ${ }^{108}$ The FMC Act does not permit the same discretion with respect to derivatives issuers. ${ }^{109}$

Even if iPredict is construed to be a derivatives issuer, which would be tenuous, the regulatory consequences would be burdensome and unnecessary. Derivatives issuers are required to provide Part 3 disclosure to all clients who are not excluded under Schedule 1 of the FMC Act ${ }^{110}$ in the form of a two part disclosure document called a product disclosure statement (PDS). ${ }^{111}$ The PDS must include a warning message; information about the derivatives; risks; fees; information about treatment of client funds and property; information about the derivatives issuer; and complaints procedures. ${ }^{112}$ The PDS must be lodged with the Registrar of Financial Service Providers, along with all other material information not contained in the PDS. ${ }^{113}$ iPredict would not be excluded from these disclosure requirements because it is a derivatives issuer and the derivatives are not issued on a licensed market. ${ }^{114}$ While traders on iPredict are anonymous, it is fair to infer that many traders are retail.

Part 3 disclosure is an expensive process but nevertheless appropriate to correct the information asymmetry between issuers and investors in most cases where Schedule 1 doesn’t apply. Derivatives are often complex products with many inherent risks deriving from the structure of the contracts, volatility of the underlying, and creditworthiness of the counterparty. ${ }^{115}$ The derivatives traded on iPredict, however, are not complex nor do they exhibit the same degree of risk. Traders do not take large positions due to contribution limits and there is no counterparty risk because iPredict acts as the clearing house. The need to correct information asymmetries therefore does outweigh the expense

\footnotetext{
108 Securities Markets Act 1988, s 37(5)(e).

${ }^{109}$ Financial Markets Conduct Act, ss 11 and 6.

${ }^{110}$ Financial Markets Conduct Act 2013, s 387(2).

111 Financial Markets Conduct Act 2013, s 48.

${ }^{112}$ Financial Markets Conduct Regulations: Exposure draft of disclosure requirements (Ministry of Business, Innovation and Employment, October 2013) at 69 - 74.

${ }^{113}$ Financial Markets Conduct Act 2013, s 48.

${ }^{114}$ Financial Markets Conduct Act 2013, sch 1, cl 20. Cl 20 also includes an exclusion for derivatives for issue or sale where the derivative is approved for sale on a prescribed overseas market; and issued by a prescribed person or class. These regulations have not yet been passed, but iPredict is not an overseas market.

${ }^{115}$ Financial Markets Conduct Regulations: Discussion Paper (Ministry of Business, Innovation and Employment, December 2012) at 58 - 60.
} 
of disclosure. iPredict would rely on the FMA granting an exemption from Part 3 disclosure to remain viable. ${ }^{116}$

Even if this exemption was granted, the licensing conditions that the FMA may impose on derivatives issuers highlight the unsuitability of the licence for iPredict. Licensing conditions largely reflect the (now revoked) Futures Industry (Client Funds) Regulations 1990 with a focus on maintaining minimum amounts of capital and liquid assets; ensuring the licensee can withstand liquidity shocks; systems for assessing the suitability of a derivative for a retail investor; and limiting the extent to which retail investors can be leveraged under a derivative. ${ }^{117}$ For iPredict, the small size of the market, simplicity and low value of the derivatives, and contribution limits make these conditions excessive. The FMA agrees, as iPredict was exempt from compliance with the Futures Industry (Client Funds) Regulations. ${ }^{118}$

\section{(ii) Financial Product Market}

iPredict will be regulated as a financial product market if it doesn't hold a market services licence. ${ }^{119}$ A financial product market is a facility by means of which offers to acquire or dispose of financial products are made or accepted. ${ }^{120}$ This is a more accurate description of how iPredict operates than derivatives issuer. iPredict would be exempt from market licensing requirements because the aggregate value of the derivatives acquired under transactions on the market is less that \$2 million per year. ${ }^{121}$ Moreover, continuous disclosure, substantial security holder disclosure, and directors' and officers' disclosure would not apply because iPredict does not facilitate offers of listed issuers. ${ }^{122}$ The residual market regulation - prohibitions on insider trading and market manipulation - would, however, frustrate the forecasting capability of the market.

\footnotetext{
${ }^{116}$ Financial Markets Conduct Act 2013, s 556.

${ }^{117}$ Financial Markets Conduct (Phase 1) Regulations 2014, reg 32.

${ }^{118}$ Futures Contracts (iPredict Limited) Declaration and Exemption Notice 2008, cl 6.

119 Financial Markets Conduct Act 2013, s 309(2)(c).

${ }^{120}$ Financial Markets Conduct Act 2013, s 309(1).

${ }^{121}$ Financial Markets Conduct Act 2013, s 312(1)(a)(ii). I have been informed by a market analyst at iPredict that the aggregate value of transactions in 2013 total $\$ 609,865.50$.

122 Financial Markets Conduct Act 2013, ss $270-307$.
} 
Insider trading regulations prohibit a person from trading where they have material information about the derivatives or the underlying that is not generally available to the market and they know, or ought reasonably to know, that the information is material and not generally available to the market. ${ }^{123}$ The rationale of this prohibition in typical financial markets is that insider trading undermines market efficiency because investors will feel at a distinct disadvantage if they believe insiders can exploit inside information, and hence won't invest. ${ }^{124}$ The same rationale is far weaker in prediction markets where information about underlyings in the public interest will generally be disclosed to the market by the media. The mischief that insider trading regulations seek to prevent can thus be overcome by creating derivatives with underlyings which don't give insiders a substantial advantage. ${ }^{125}$ Even where relevant information is not in the public domain, insider trading regulations are antithetical to the forecasting capability of the market; the accuracy of which relies, in part, on insiders trading on all the information they hold. ${ }^{126}$

Market manipulation regulations prohibit conduct that creates a false impression of trading activity, price movement, or market information. ${ }^{127}$ This is also a concern in prediction markets where an accurate price signal is essential to its forecasting capability. In practice, however, attempts at market manipulation have been consistently unsuccessful because well-informed traders can easily profit from manipulative trades due to the low purchase price of the derivatives. Market manipulation in prediction markets therefore tends to increase market liquidity rather than undermine it. ${ }^{128}$

Most importantly, insider trading and market manipulation regulations entail criminal liability that would be wholly disproportionate to the harm of the activity in prediction

\footnotetext{
${ }^{123}$ Financial Markets Conduct Act 2013, s 241. Information insiders are also prohibited from disclosing inside information or advising or encouraging trading (ss $242-243$ ).

${ }^{124}$ Stace, above n 5, at 284.

${ }^{125}$ Erik Snowberg, Justin Wolfers and Eric Zitzewitz "Information (in)efficiency in prediction markets" in Leighton Vaughan Williams (ed) Information Efficiency in Financial and Betting Markets (Cambridge University Press, New York, 2005) at $374-375$.

${ }^{126}$ McCarthy, above n 27, at 751.

${ }^{127}$ Financial Markets Conduct Act 2013, ss 262 and 265.

${ }^{128}$ Robin Hanson, Ryan Oprea, and David Porter "Information aggregation and manipulation in an experimental market” (2006) 60 Journal of Economic Behaviour \& Organisation 499 at 453.
} 
markets. ${ }^{129}$ The possibility of severe criminal penalty weighed against the potential for small profits would deter even the most law-abiding traders. Exemptions from compliance with insider trading and market manipulation regulations would be necessary for efficiency and confident participation in the market, but would have the unusual result of exempting iPredict from the only market regulations that apply under Part 5 of the FMC Act. ${ }^{130}$ iPredict would consequently be a financial product market in name only.

\section{RECOMMENDATIONS}

\section{(i) Designation}

Pursuant to the discussion in Part IV Subpart D, this paper recommends that the FMA makes a declaration that all the contracts traded on iPredict are derivatives.

\section{(ii) Market Services Provider: Prescribed Intermediary Service}

The FMC Act creates new 'prescribed intermediary service' licenses which provide the template for a more coherent approach to the regulation of prediction markets. These licenses were introduced to promote innovative developments in online fundraising: equity crowd-funding and peer-to-peer (P2P) lending. ${ }^{131}$ Equity crowd-funding is a service that facilitates offers of shares by matching companies who wish to raise funds from many investors who are seeking to invest relatively small amounts. P2P lending is a service that facilitates small loans by matching borrowers to one or more lenders. ${ }^{132}$ While the capital-raising purposes of the current prescribed intermediaries are clearly unlike the forecasting purpose of iPredict, the regulation that accompanies licensing is strikingly similar to how iPredict has been regulated to date.

Creation of special licences for equity crowd-funding and P2P lending platforms is intended to encourage small-scale funding of start-up companies by minimising

\footnotetext{
${ }^{129}$ Financial Markets Conduct Act 2013, ss 244 and 269.

${ }^{130}$ Financial Markets Conduct Act 2013, s 556.

${ }^{131}$ Financial Markets Conduct (Phase 1) Regulations 2014, reg 15.

132 Office of the Minister of Commerce, above n 82, at $12-16$.
} 
regulatory burden. ${ }^{133}$ Intermediaries, as well as issuers, must provide a substantially less onerous "disclosure statement" in lieu of a PDS. ${ }^{134}$ For intermediaries, this disclosure statement contains a brief description of, inter alia, the nature of the service; eligibility criteria for investors and issuers who use the service; how money is made under the service; how investor money is dealt with; the nature and extent of disclosure; fees; and complaint procedures. ${ }^{135}$ The disclosure must be given to retail investors before they enter into a client agreement with the intermediary; ${ }^{136}$ an agreement which largely replicates the contents of the disclosure statement. ${ }^{137}$ Under iPredict's current authorisation, iPredict enters into "participation agreements" with traders, and the terms and conditions of participation agreements are very similar to the prescribed contents of disclosure and intermediary client agreements. ${ }^{138}$

The eligibility criteria for intermediary service licences also closely corresponds to iPredict's current regulation. Intermediaries must have systems to ensure that issuers do not raise more than $\$ 2$ million per year via the intermediary. ${ }^{139}$ This "investment cap" reflects the FMA's approach to regulation of iPredict under the SM Act, whereby traders are subject to contribution limits of \$2,500 in a period of 6 months and a cumulative total limit of $\$ 10,000 .{ }^{140}$ Intermediary services must be fair, orderly and transparent neutral brokers between issuers and investors, in that the service is designed primarily for offers by persons other than the provider and the service must not give investment advice. ${ }^{141}$ Equally, iPredict acts as a neutral broker between traders and does not offer advice about the profitability of its contracts.

\footnotetext{
${ }^{133}$ Anna Buchly and Ben McTaggart Crowdfunding - A Viable Alternative to Capital Raising (Bell Gully, February 2013) at 3.

${ }^{134}$ Financial Markets Conduct Act 2013, s 423.

135 Financial Markets Conduct (Phase 1) Regulations 2014, reg 36.

${ }^{136}$ Financial Markets Conduct (Phase 1) Regulations 2014, reg 35.

${ }^{137}$ Financial Markets Conduct (Phase 1) Regulations 2014, reg 45 and 46.

138 iPredict "Terms of Service" < www.ipredict.co.nz>

${ }^{139}$ Financial Markets Conduct (Phase 1) Regulations 2014, reg 17(g) and 18(g).

${ }^{140}$ Futures Contracts (iPredict Limited) Declaration and Exemption Amendment Notice 2011, reg 5.

${ }^{141}$ Financial Markets Conduct (Phase 1) Regulations 2014, reg 17(1)(a) and (b), and 18(1)(a) and (b).

“Neutral broker” terminology from Office of the Minister of Commerce above n 82, at 13.
} 
Intermediaries must be registered under the Financial Service Providers (Registration and Dispute Resolution) Act 2008 if they provide a broking service, ${ }^{142}$ i.e. receive and hold, pay, or transfer client money in connection with financial products. ${ }^{143}$ Client money must be held on trust, ${ }^{144}$ and account records must be kept in a manner that enables those records to be conveniently audited. ${ }^{145}$ iPredict's current authorisation details very similar requirements: funds paid by traders to the clearing house must be held on trust by a separate custodian (the clearing house Predictions Clearing Limited) in individual ledgers, and the financial statements of the clearing house must be audited annually. ${ }^{146}$

These similarities indicate that the regulations enacted for crowd-funding and P2P lending can be largely transposed onto prediction markets. Accordingly, this paper recommends that regulations are passed to include prediction markets as a third prescribed intermediary service under the FMC Act. Eligibility criteria will, of course, not pertain to issuers but prediction markets should have comparable fair, orderly, and transparent systems and procedures:

- To ensure retail traders receive a timely and understandable service disclosure statement to assist traders to decide whether to acquire the derivatives:

- To ensure retail traders enter into a client agreement with the service provider before they acquire the derivatives:

- To ensure traders do not exceed the contribution limit (to be decided by the FMA) for the credit of his or her account with the clearing house:

- To identify and manage the risk of fraud by traders, for example, in the event that a trader opens more than one trading account.

The FMA may also impose conditions on a licence. This paper recommends conditions that limit prediction market intermediaries to facilitating trades of derivatives with underlyings in which there is legitimate public interest. As to additional conditions, P2P lending and equity crowd-funding is relatively new territory and Government has opted

\footnotetext{
${ }^{142}$ Financial Markets Conduct (Phase 1) Regulations 2014, reg 17(1)(i) and 18(1)(i).

${ }^{143}$ Financial Advisers Act 2008, s 77B.

${ }^{144}$ Financial Advisers Act 2008, s 77P.

145 Financial Advisers Act 2008, s 77R.

${ }^{146}$ Futures Contracts (iPredict Limited) Declaration and Exemption Notice 2008, reg 7.
} 
for a flexible approach subject to careful supervision by the FMA. ${ }^{147}$ This paper recommends that the same approach is taken to the regulation of prediction markets as a platform also in its early stage of development. ${ }^{148}$

\section{CONCLUSION}

Prediction market derivatives provide financial incentives for truthful revelation and information discovery, and an algorithm for aggregating diverse opinions on the probability of an event. The experience of iPredict to date has shown that these features collaborate to generate forecasts on issues of public concern which are frequently more accurate than conventional forecasting tools. iPredict's market prices therefore have a great deal of potential to inform public and private decision-making, but whether this potential can be realised under the FMC Act is unclear. This is not surprising: prediction market derivatives are not clearly securities. Nor do the markets sit neatly within gambling legislation where they would otherwise fall to be regulated and, in that case, prohibited. Accordingly, this paper proposed to find a place in securities law for these innovative markets.

Regulation of iPredict under the FMC Act is possible but the hurdles are not insignificant. iPredict would rely on a declaration by the FMA that its contracts are derivatives and substantial exemptions from regulation compliance under the existing regulatory categories of derivatives issuer and financial product market. Such exemptions, while desirable, would render regulation relatively artificial in its application to iPredict.

This paper recommends a more coherent approach to the regulation of prediction markets by drawing from the regulation of other intermediaries that harness the power of online crowds. Crowd-funding and P2P lending platforms are similar to iPredict in many respects - neutral brokers between retail investors/traders for small amounts of funds through an online platform - and regulation of iPredict under the SM Act bears striking similarity to regulation under these new licenses. The existing prescribed intermediaries, however, have

\footnotetext{
${ }^{147}$ Office of the Minister of Commerce, above n 82, at 16.

148 The requirement of a warning statement, however, is likely to be inappropriate considering the low value of the derivative contracts.
} 
the distinct advantage of sitting within the Government's current Business Growth Agenda. ${ }^{149}$ Until prediction markets attract the same legislative attention, it seems probable the markets will persist in legal limbo.

${ }^{149}$ Bill English and Steven Joyce The Business Growth Agenda: Future Direction 2014 (Ministry of Business, Innovation and Employment, 2014) at 6. 


\section{BIBLIOGAPHY}

\section{Legislation and regulations}

Financial Advisers Act 2008.

Financial Markets Conduct Act 2013.

Financial Markets Conduct (Phase 1) Regulations.

Futures Contracts (iPredict Limited) Declaration and Exemption Notice 2008.

Futures Contracts (iPredict Limited) Declaration and Exemption Amendment Notice 2011.

Futures Contracts (iPredict Limited) Declaration and Exemption Amendment Notice (No 2) 2013.

Financial Markets Conduct Bill (342-1) (explanatory note).

Gambling Act 2003.

Securities Markets Act 1988.

\section{Cases}

Morgan Grenfell \& Co Ltd v Welwyn Hatfield District Council (Islington London Borough Council, third party) [1995] 1 ALL ER 1.

TV Works v Department of Internal Affairs [2012] NZCA 160.

\section{Books and chapters in books}


Friedman, Milton and Friedman, Rose Free to Choose (Penguin Books, Australia, 1981).

Hull, John C. Fundamentals of Futures and Options Markets ( $8^{\text {th }}$ ed, Pearson Education, USA, 2014).

McGirr, Shaun and Salmond, Rob "2008: Opinion Polls and Prediction Markets in New Zealand” in Stephen Levine and Nigel S. Roberts (eds.) Key to Power: The General Election of 1009 (Victoria University Press, Wellington, 2010) 255 - 272.

Snowberg, Eric, Wolfers, Justin and Zitzewitz, Eric "Information (in)efficiency in prediction markets” in Leighton Vaughan Williams (ed) Information Efficiency in Financial and Betting Markets (Cambridge University Press, New York, 2005) 366 - 386.

Stace, Victoria Securities Law in New Zealand (LexisNexis, Wellington, 2010).

Sunstein , Cass R. A Constitution of Many Minds: Why the Founding Document Doesn't Mean What It Meant Before (Princeton University Press, New Jersey, 2009).

Surowieki, James The Wisdom of Crowds: Why the Many Are Smarter Than the Few and How Collective Wisdom Shapes Business, Economies, Societies, and Nations (Doubleday, New York, 2004).

\section{Journals}

Allensworth, Rebecca Haw "Prediction Markets and the Law: A Skeptical Account” (2009) 122 Harvard Law Review 1217 - 1238.

Arrow, Kenneth J., Forsyth, Robert Gorham, Michael Hahn, Robert Hanson, Robin Ledyard, John O. Levmore, Saul Litan, Robert Milgrom, Paul Nelson, Forrest D. Neumann, George R. Ottaviani, Marco Schelling, Thomas C. Shiller, Robert J. Smith, Vernon L., Snowberg, 
Erik Sunstein, Cass R. Tetlock, Paul C. Tetlock, Philip E. Varian, Hal R. Wolfers, Justin and Zitzewitz, Eric “The Promise of Prediction Markets” 320 Science 877 - 878.

Awrey, Dan “The Dynamics of OTC Derivatives Regulation: Bridging the Public-Private Divide” (2010) 11 European Business Organisation Law Review 155 - 193.

Awrey, Dan “Complexity, Innovation, and the Regulation of Modern Financial Markets” (2012) 2 Harvard Business Law Review 253 - 294.

Berg, Joyce E., Nelson, Forrest D., and Reitz, Thomas A. "Prediction market accuracy in the long run” (2008) 24 International Journal of Forecasting 283 - 298.

Bragues, George "Prediction Markets: The Practical and Normative Possibilities for the Social Production of Knowledge” (2009) 6 Episteme 91 - 106.

Bell, Tom W. “Government Prediction Markets: Why, Who, and How” 166 Penn State Law Review 403 - 436.

Chen, Jenny and Watson, Susan "Investor Psychology Matters: Is a Prescribed Product Disclosure Statement a Supplement for Healthy Investment Decisions? (2011) 17 NZBLQ $412-440$.

Cherry, Miriam A. and Rogers, Robert L. "Prediction Markets and the First Amendment" (2008) University of Illinois Law Review 833 - 880.

Dalziel, Hon Lianne “Guest Editorial: Securities Market Regulation: The Minister’s right of reply” [2003] 4 CSLB 29 - 32.

Fama, Eugene F. “Efficient Capital Markets: A Review of Theory and Empirical Work” 25 The Journal of Finance $383-417$. 
Feder, Norman Menachem “Deconstructing Over-The-Counter Derivatives (2002) Columbia Business Law Review 677 - 748.

Griffiths, Shelley "Regulating Private Offers of Securities: Time for a Major Rethink" (2009) 15 NZBLQ $105-123$.

Hanson, Robin, Oprea, Ryan and Porter, David "Information aggregation and manipulation in an experimental market” (2006) 60 Journal of Economic Behaviour \& Organisation 449 $-459$.

Hanson, Robin “Shall We Vote on Values, But Bet on Beliefs?” (2013) 21 The Journal of Political Philosophy $151-178$.

Hahn, Robert W. and Tetlock, Paul C. “A new approach for regulating information markets” (2006) 29 Journal of Regulatory Economics 265 - 281.

Hawkesby, Christian A primer on derivatives markets (2009) 62 Reserve Bank of New Zealand Bulletin $24-43$.

Hayek, Friedrich “The Use of Knowledge in Society” (1945) 35 The American Economic Review 519 - 530.

Hazen, Thomas Lee “Disparate Regulatory Schemes for Parallel Activities: Securities Regulation, Derivatives Regulation, Gambling, and Insurance” (2005) 24 Annual Review of Banking and Finance Law 357 - 442.

Holland, Chris “Financial Markets Conduct Act - An Overview, Part One” (2013) CSLB $77-83$.

Hurt, Christine "Regulating Public Morals and Private Markets: Online Securities Trading, Internet Gambling, and the Speculation Paradox” (2006) 86 Boston University Law Review $371-442$. 
Lynch, Timothy E. “Derivatives: A Twenty-First Century Understanding (2011) 43 Loyola University of Chicago Law Journal $1-51$.

McCarthy, Ryan P. “Information Markets as Games of Chance” (2007) 155 University of Pennsylvania Law Review 749 - 776.

Rose, Nelson "How Securities Trading Became Legally Not Gambling” (2011) 15 Gaming Law Review and Economics 249 - 253.

Servan-Schreiber, Emile, Wolfers, Justin, Pennock, David M. and Galebach, Brian “Prediction Markets: Does Money Matter?” (2004) 14 Electronic Markets 243 - 251.

Stout, Lynn A. "Why the Law Hates Speculators: Regulation and Private Ordering in the Market for OTC Derivatives” (1999) 48 Duke Law Journal 701 - 786.

Sunstein, Cass R. “Group Judgments: Statistical Means, Deliberation, and Information Markets” (2005) 80 New York University Law Review 962 - 1049.

Wolfers, Justin and Zitzewitz, Eric “Prediction Markets” (2004) 18 The Journal of Economic Perspectives $107-126$.

\section{Papers and reports}

A Guide to the Financial Markets Conduct Act 2013 Reforms (Financial Markets Authority, November 2013).

Buchly, Anna and McTaggart, Ben Crowdfunding - A Viable Alternative to Capital Raising (Bell Gully, February 2013).

Cameron, Rob Capital Markets Matter (Capital Markets Development Taskforce, December 2009). 
Chen, Kay-Yut and Plott, Charles R. Information Aggregation Mechanisms: Concept, Design and Implementation for a Sales Forecasting Problem (California Institute of Technology, 2002).

Cogill, Bo Wolfers, Justin and Zitzewitz, Eric Using Prediction Markets to Track Information Flows: Evidence from Google (Dartmouth College, 2008).

D’Hulster, Katia The Leverage Ratio: A New Binding Limit on Banks (World Bank Group, December 2009).

English, Bill Budget Policy Statement (New Zealand Treasury, December 2013).

English, Bill and Joyce, Steven The Business Growth Agenda: Future Direction 2014 (Ministry of Business, Innovation and Employment, 2014).

Hanson, Robin Shall We Vote on Values, But Bet on Beliefs? (George Mason University, working paper, 2000).

Financial Markets Conduct Bill Exposure Draft: Table of Submissions and Ministry Comments (Ministry of Economic Development, October 2011).

Financial Markets Conduct Regulations: Discussion Paper (Ministry of Business, Innovation and Employment, December 2012).

Financial Markets Conduct Regulations: Exposure draft of disclosure requirements (Ministry of Business, Innovation and Employment, October 2013).

NZX Guide to Dairy Futures: NZX Derivatives Market (NZX, 2013).

Office of the Minister of Commerce Financial Markets Conduct Regulations Paper 4 Licensing Regimes (Cabinet Business Committee, September 2013). 
Review of Securities Law Discussion Paper (Ministry of Economic Development, June 2010).

\section{Websites}

www.ipredict.co.nz

The word count of this paper (excluding cover page, contents, abstract, bibliography and non-substantive footnotes) is 7,869 . 